\title{
ТЕХНОЛОГІЯ НАОЧНОГО МОДЕЛЮВАННЯ ЯК ЗАСІБ РОЗВИТКУ КОМУНІКАТИВНИХ ЗДІБНОСТЕЙ ДІТЕЙ ДОШКІЛЬНОГО ВІКУ
}

\begin{abstract}
Анотація. У статті розглядається сучасний підхід до розвитку комунікативних здібностей дітей дошкільного віку через використання методу наочного моделювання. Зазначено, що спілкування $е$ важливою умовою правильного та повноцінного розвитку дитини дошкільного віку, зокрема спілкування 3 дорослим - основною і вирішальною умовою формування комунікативних здібностей дитини: мовлення, мислення емоційної сфери, самооцінки, уяви. За допомогою методу наочного моделювання у дітей поступово формуються зв'язність, послідовність, наполегливість, викладення власної думки, розвивається словниковий запас, синтаксичний лексико-граматичний лад мови, що слугує тямущому мовленнєвому висловлюванню. Комунікащія - один із основних засобів реалізації завдання адаптації дитини до нових умов. Від рівня спілкування залежить не лише навчальна діяльність, а й саме життя дитини.
\end{abstract}

Ключові слова: наочне моделювання, комунікація, схеми-моделі, мнемотаблиці, зв'язне мовлення.

Borovyk Liudmyla T.H. Shevchenko National University "Chernihiv Colehium"

\section{TECHNOLOGY OF VISUAL MODELING AS A MEANS OF DEVELOPMENT OF COMMUNICATIVE ABILITIES OF PRESCHOOL CHILDREN}

Summary. The article considers the development of communicative abilities of preschool children through the use of the method of visual modeling. It is noted that communication is an important condition for proper and full development of a preschool child, in particular communication with an adult - the main and crucial condition for the formation of communicative abilities of the child: speech, emotional thinking, self-esteem, imagination. It has been determined that the simulation itself helps to quickly memorize the content of new material. A child's communication is not only the ability to make contact and have a conversation, but also the ability to listen carefully and actively and hear, using facial expressions and gestures to express their thoughts more expressively. With the help of the method of visual modeling, children gradually form coherence, consistency, persistence, presentation of their own opinion, develop vocabulary, syntactic lexical and grammatical structure of language, which serves intelligent speech. The depth of development of collective speech of preschoolers is most fully revealed. The result of using this direction is the child's mastery of the schematic model of the ability to compare the illustration with a real object. It is the illustration that replaces the subject at the preparatory stage. Then there is an acquaintance with the conditionally real image of the object. For the development of communicative abilities of preschool children use substitute symbols, schemes-models, mnemonics, comparative models. The story according to the plot picture, the construction of simple, complex sentences, with the help of a mnemonic table becomes more diverse. Children with medium and low levels of memory involuntarily learn the poem in everyday life, paying attention to the "hint". To identify self-control and self-assessment of guessing and guessing riddles. The use of didactic games promotes the development of preschool speech skills. Thus, the relevance of the use of visual modeling in working with children is that: does not cause fatigue and loss of interest in classes; the use of schematic analogy facilitates and accelerates the process of memorization and assimilation of the material forming, methods of working with memory; the use of graphic analogy helps children see the main thing, to systematize the acquired knowledge. The results of the study prove that the use of model schemes is one of the effective ways to promote the development of speech, verbal and logical thinking, memory of preschool children. Children work more actively in the classroom due to the concentration of observation, attention, memory, perseverance. Creative imagination, logical and figurative thinking develop, preschoolers are more active in the desire to communicate with peers and adults, overcome cowardice, shyness. Keywords: visual modeling, communication, model schemes, mnemonics, coherent speech.

$\Pi^{2}$ остановка проблеми. Проблема розвитку комунікативних навичок дошкільників не є новою. Вона аналізувалася класиками наукової думки і сучасними науковцями. Це В.В. Гербова, Л.С. Виготський, Г.М. Піроженко, А.М. Богуш, Н.В. Гавриш, Т.О. Леушина та інші. Комунікативні здібності - це можливості вміти володіти ініціативою в спілкуванні, проявляти активність, емоційно реагувати на стан партнерів спілкування, майстерність сформувати i реалізувати особисту індивідуальну програму спілкування [3, с. 17].

В сучасних умовах динамічний характер життя вимагає від дитини вміння вживатися швидко в дитячому колективі, творчо мислити, бути го- товим адаптуватися до нових умов. Особливо ця проблема стосується дітей старшого дошкільного віку, які у певний час мають змінити дитячий колектив у дошкільному навчальному закладі на новий - учнівський колектив у початковій школі.

Комунікація - це один із засобів основних адаптації втілення дитини до нових умов. Від рівня спілкування залежить не лише навчальна активність, а й саме життя дитини. Дитина дошкільного віку дуже гнучка і легко вчиться, але для більшості дітей характерною е бистра стомлюваність і втрата защікавленості до заняття. Використання наочного моделювання викликає зацікавленість і сприяе розв'язати цю проблему. 
Метод моделювання вперше придумали психологи й педагоги: Д.Б. Ельконін, Л.А. Венгер, Н.О. Ветлугіна, М.М. Подд'яков. Цей спосіб полягає у тому, що мислення, думку дитини розвивають за допомогою спеціальних схем, моделей, мнемо таблиць які в наочній і доступній формі відтворюють сховані особливості та взаємозв'язки того чи іншого об'єкта [7, с. 13-23].

Аналіз останніх досліджень і публікацій. Сучасні підходи у розвитку мовлення дітей в дошкільній педагогіці з'ясовували А.М. Богуш, Н.В. Гавриш, А.В. Омельяненко, А.В. Гончаренко, К.Л. Крутій та інші науковці. Охоплення мовленням як засобом осягнення і способом людського спілкування $е$ найвагомішими досягненням дошкільного дитинства. Дуже важливе місце в системі засобів розвитку мовлення дошкільників займає використання наочності, за допомогою якої педагог має можливість змінити мовленневу діяльність дошкільників у цікавий та доступний дітям вид діяльності. Так, Л.О. Венгер виявив, що засобом мислення дітей дошкільного віку є наочні моделі, в яких дитина відтісняе структуру об'єктів і спільності між ними. Один з таких елементів на думку С.Л. Рубінштейна, А.М. Леушина, Л.В. Ельконіна та інших - наочність. Розглядання предметів, картин допомагае дітям називати предмети, їх характерні властивості зв'язані з ними дії. В якості другого допоміжного фактора ми виділимо створення плану розкриття, на значимість якого неодноразово вказував відомий психолог Л.С. Виготський. Він відзначав важливість послідовного один за одним розміщення в попередній схемі всіх конкретних елементів висловлювання. К.Д. Ушинський писав: «Учить дитину якимось невідомим йому п'яти словам - вона буде довго і марно мучитися, але пов'язати двадцять таких слів з картинками, і вона засвоїть їх на льоту». Цей метод є одним із перспективних методів реалізації розумового виховання та розвитку мовлення дошкільників, так як мислення малюків відрізняеться предметною мальовничістю та наочною конкретністю, реальністю [2, с. 313].

Виділення невирішених раніше частин загальної проблеми. Використання предметносхематичних моделей на думку психологів, педагогів та логопедів, полегшуе процес розвитку зв'язного мовлення (О.П. Д'яченко, В.П. Воробйова, В.С. Глухов, Л.Н. Єфіменкова, Т.І. Ткаченко та інші). Моделі, передаючи структуру розповіді та ï послідовність, підпорядковуються своерідним наочним "планом» для створення монологів, тому вони успішно використовуються в практищі. На сучасному етапі розвитку освіти використання методу наочного моделювання є актуальним для різних сфер пізнавальної діяльності дітей, оскільки доведено його ефективний вплив на пізнавальну активність дітей, розвиток послідовного, логічного мислення, підвищення інтересу власної мови, на розвиток пам'яті, уяви, виховання самостійності, самодостатності й впевненості в собі [5, с. 85].

Формулювання цілей статті - обтрунтування доречності застосування методу наочного моделювання як засобу розвитку комунікативних здібностей.

Виклад основного матеріалу. У Базовому компоненті дошкільної освіти висловлено, що мовленнева компетенція - це розуміння дітьми зв'язного тексту, звертатися із запитаннями, вміння відповідати на запитання і розпочинати та підтримувати розмову, вести діалог, складати різні види розповідей, описів. Використовуючи метод наочного моделювання цього можна навчити застосовуючи метод наочного моделювання $[1$, c. 26$]$.

Компонентом найважливішим успішного процесу розвитку комунікативних здібностей $е$ насичення мовленневого середовища, в якому перебуває малюк, зразками рідної мови та створення спеціальних допоміжних умов, які допомагатимуть дитині будувати своє висловлювання. Однак досить важливим компонентом розвитку комунікативних здібностей дітей $е$ формування граматичної будови мови - означае навчатися певних знань правильно вживати різні відмінкові закінчення слів, дієслівні форми та їх видозміни, суфрікси, префікси, встановити відповідність частини мови, правильно будувати речення, дотримуючи відповідного порядку слів у ньому. Використовуючи наочний запис розповідних, питальних, заперечних, порівняльних речень можна вчити дитину встановлювати відповідність слова в реченні. Для цього використовують вправи та дидактичні ігри на основі наочних моделей.

Наочне моделювання - це відображення суттевих особливостей досліджуваного об'єкта, створення його замінника і робота з ним. Оперування наочними моделями є основними, головними, пізнавальними здібностями дошкільника. Головний шлях розвитку пізнавальних здібностей - це постійний перехід від зовнішніх дій із умовними замінниками предметів (мнемо таблицями, схемами-моделями,) до дій подумки. Тож, моделювання -заміщення об'єкта, який вивчається, іншим, спеціально побудованим, що може відтворювати об’ект в його значних якостях і спрощувати не значні.

Завдання методу:

- вчити дітей граматично правильно, послідовно, та зв'язно висловлювати свою думку;

- вчити переказувати невеликі твори;

- удосконалювати діалогічну мову;

- вчити описувати предмет, картину;

- виховувати бажання говорити як дорослий.

- формувати вміння підтримувати діалог, вільно, невимушено вступати в розмову;

- вчити розповідати за змістом сюжетну розповідь.

Наочне моделювання ефрективно використовують для донесення дітям різноманітних знань, а також як засіб розвитку розумових і мовленневих їх здібностей. В основі методу лежить використання замінника (моделі), яким можуть слугувати схеми, креслення, плани, умовні позначення, силуетні й стилізовані зображення, піктограми й інші предмети. Інструментом пізнання у дошкільній педагогіці може стати модель, що дозволяе дитині формувати творчу уяву абстрактних понять (слово, звук, текст), з ними вчитися працювати.

Доступне донесення дітям дошкільного віку алгоритмів складання описових розповідей є дуже важливим для їх розвитку. Вміння дитини лаконічно, точно й образно описувати предмет сприяе вдосконаленню іiі мови, мислення, полегшуе процес обміну інформаціею. Наочні опорні схеми помітно спрощують завдання, роблять висловлюван- 
ня зв'язними, чіткими та послідовними. Основу описової розповіді складають конкретні уявлення, які накопичуються в процесі обстеження об'єкту опису. Описової розповіді елементами моделі стають символи-замінники якісних характеристик об'єкту: належність до родового поняття, колір, величина, деталі, форма, матеріал, з якого виготовлений предмет, якість поверхні, за що подобається, як використовується. За цією моделлю можна описати будь-який окремий предмет [6, с. 192].

Наприклад:

Діти порівнюють предмети, визначаючи спочатку їх подібність, а потім відмінність.

Порівняльний опис лисиці і зайця

Лисиця і заєць - це дикі тварини. Заєць - маленький, а лисиця - більша. У зайця літом хутро сірого кольору, а у лисиці рудого. Заєць - їсть овочі, а лисиця - хижак.

(Схема-модель 1)
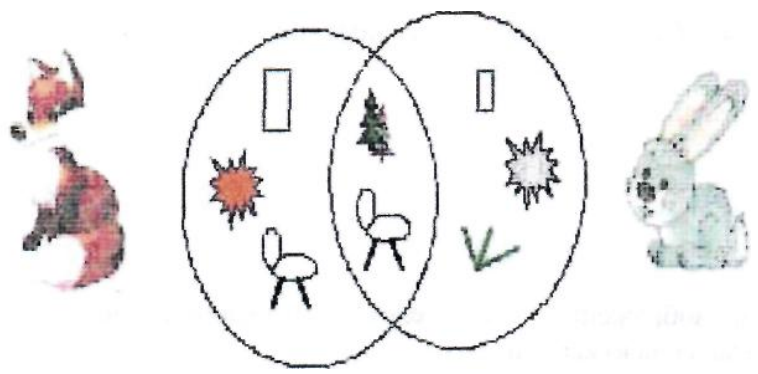

За сюжетною картиною картинно-графічний план для розповіді просто необхідний. Дитині важко сконструювати ситуацію, зображену на картині, придумати розвиток подій і грамотно закінчити свою розповідь, тобто оформити мовним матеріалом схему побудови висловлювання: зачин - розвиток подій - підсумок. Складність опису навчання обумовлена тим, що для створення i розуміння такого фрункціонального типу мови не достатньо накопиченого життевого досвіду, а необхідна активна інтелектуальна робота самої дитини 3 виділення ознак і особливостей явища чи предмета. Перш ніж описувати предмет, дитина повинна навчитися виділяти найбільш суттеві риси предмета, підбирати точні слова, висловлювати своє ставлення до описуваного предмету і граматично правильно офрормляти фразу. Використовуючи метод моделювання навчати дитину підбирати предмети, дії, поняття, явища, епізоди тексту за допомогою знаків, спрощених схематичних зображень-символів.

При всьому необхідно враховувати загальнопедагогічні принципи дидактики, зокрема, поетапність засвоєння дітьми рідної мови:

- збагачення словникового запасу;

- побудова простих речень;

- складання зв'язної розповіді, спираючись на низку символів, у кожному конкретному випадку $[4$, c. 33].

Направлені види роботи, на використання методу наочного моделювання, подані в таких напрямках:

- вміння описувати предмет і складати розповідь;

- вміння аналізувати: виділяти суттєве, істотне, знаходити відмінне і спільне, відшукувати протиріччя;
- навчання допитливості і спостережливості;

- підвищення інтересу до вивчення рідної мови.

Вправи з використанням методу наочного моделювання на заняттях художньої літератури (переказ казок, оповідань, загадок, заучування віршів) розвитку мовлення (складання описових розповідей, речень за аналогією, навчання складати творчі розповіді, казки), направлені на з'ясування завдань Базового компонента.

Мнемо таблиці - це графічне або частково графрічне зображення явищ природи, персонажів казки, деяких дій та інших шляхом виділення головних смислових ланок сюжету оповідання. Головне потрібно передати схему умовно-наочну, зобразити так, щоб намальоване було зрозуміло дітям [4, с. 28].

Застереження практичного використання даного напряму роботи є опанування дитиною схематичної моделі, вміння зіставляти ілюстрацію 3 реальним предметом. Саме ілюстрація виступає замінником предмета на підготовчому етапі. Далі відбувається ознайомлення з умовно-реальним зображенням предмета, коли в ньому зберігаються ще деталі та яскраві ознаки, але вони представлені вже схематично [7, с. 18].

Таким чином, під час розвитку навичок наочного моделювання вирішуються такі дидактичні завдання:

- ознайомлення із графрічним способом уявлення інфрормації;

- розвиток уміння дешифрувати модель;

- фрормування навичок самостійного моделювання

Мнемо таблиці-схеми є дидактичним матеріалом з розвитку зв'язного мовлення дітей і використовувати їх для:

- описання предметної картинки;

- описання сюжетної розповіді за змістом;

- загадуванні і відгадуванні загадок;

- заучуванні віршів.

За сюжетною картинкою розповідь дозволить дитині будувати речення. Тому зміст картинок слід підбирати такий, щоб дитина мала можливість скласти речення різної складності. Двослівне речення: “Дівчинка грається». Трислівне речення: «Хлопчик приніс кораблик».

Багатослівні: «Хлопчик з дівчинкою прийшли до річки». Складні речення: «Діти вийшли погратися у сонячну погоду».

(Сюжетна картина 2)

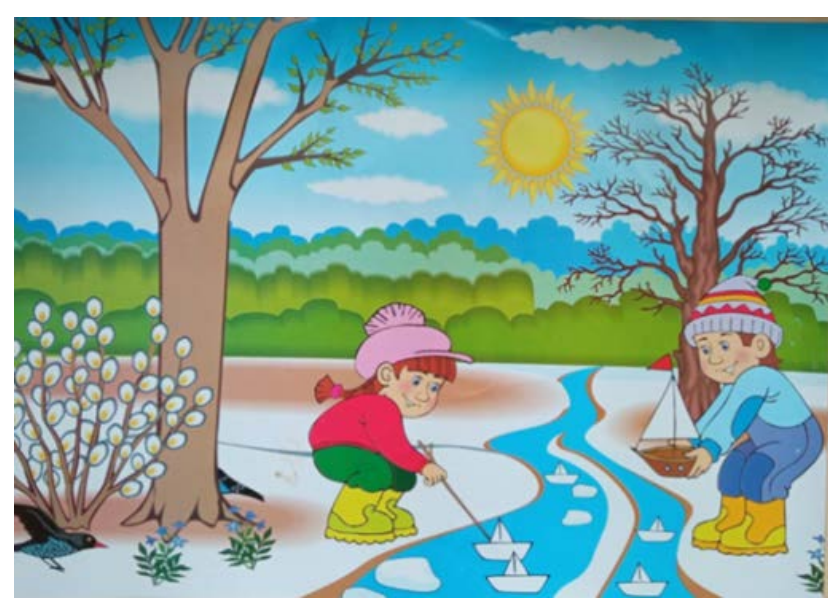


За допомогою наочного моделювання діти оволодівають навичками:

- здобувати індормацію;

- проводити дослідження;

- робити порівняння;

- складати чіткий внутрішній план розумових дій, мовного

висловлювання;

- формулювати і висловлювати думки;

- робити висновки.

Ефективно також використовувати схеми-моделі під час вивчення напам'ять віршованих творів. Варто умовними схематичними позначеннями зашифррвати кожен рядок вірша (або пару) і вивісити таку схему на видному місці. Вивчати вірші, спираючись на дитячі інтереси не примушуючи та на достатній розвиток наочно-образного мислення в цьому віщі.

(Мнемо таблиця 3)

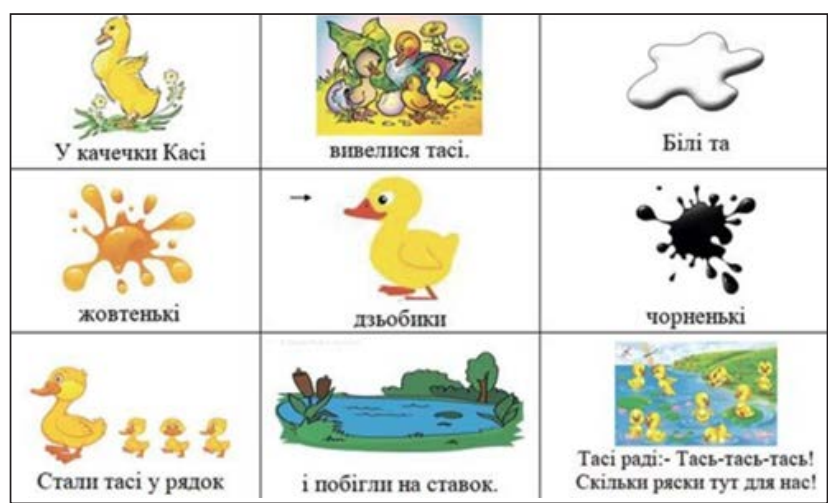

Схеми - моделі, мнемо таблиці відіграють значну роль у диференційованому навчанні. Діти з середнім і низьким рівнем розвитку пам'яті мимоволі вчать вірш у повсякденному житті, звертаючи увагу на "підказку». Для дітей 3 достатнім і високим рівнем розвитку схема виявляеться засобом самоконтролю та самооцінки. Діти з високим рівнем розвитку схематично зображують знайому загадку, а діти з низьким і середнім рівнем - відгадують.

Я придумаю загадку, запишу іï на згадку.

Можна використовувати ï для побудови речень із запереченнями, а також для складання загадок на їх основі. Наприклад:

(Схема-модель 4)

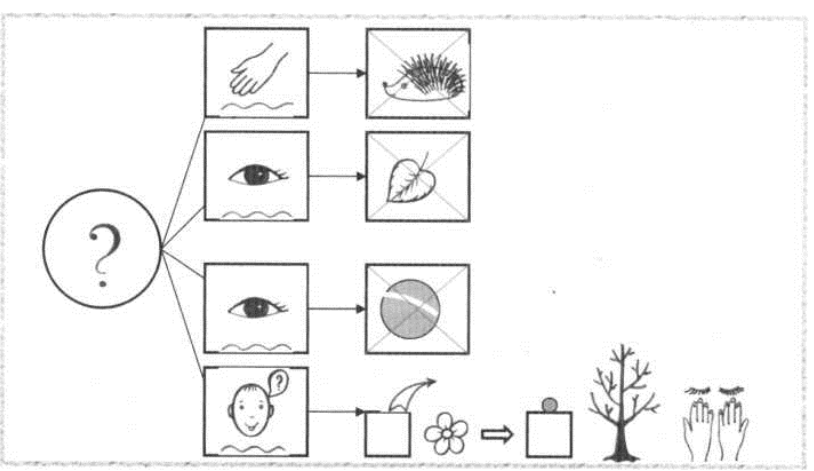

«Колючий а не їжачок; зелений, а не листочок; кругленький, а не м'ячик, він із квіточки з'являеться і на дереві ховається. Що це?» (Каштанчик).
Це слугує налагодженню товариських стосунків, формуванню адекватної самооцінки у дітей, а головне - підготовці малюків до оволодіння завданнями програмними в школі [7, с. 13-23].

Роботу на заняттях з мнемо таблицями потрібно будувати поетапно.

I етап. Розглядання таблиці і розбір того, що на ній зображено.

II етап. Здійснення перекодування інформації, тобто перетворення з абстрактних слів символів в образи.

III етап. Після перекодування здійснення переказу розповіді або казки на задану тему. У молодших групах за допомогою вихователя, в старших - діти самостійно розповідають або переказують.

Розповідь за допомогою мнемо таблиці:

Настала весна. Сонечко розтопило сніг. З'явилася травичка. Розквітли перші весняні квіти. 3 вирію повернулися птахи. На деревах з'явилися перші листочки. Діти радіють сонечку.

(Мнемо таблиця 5)

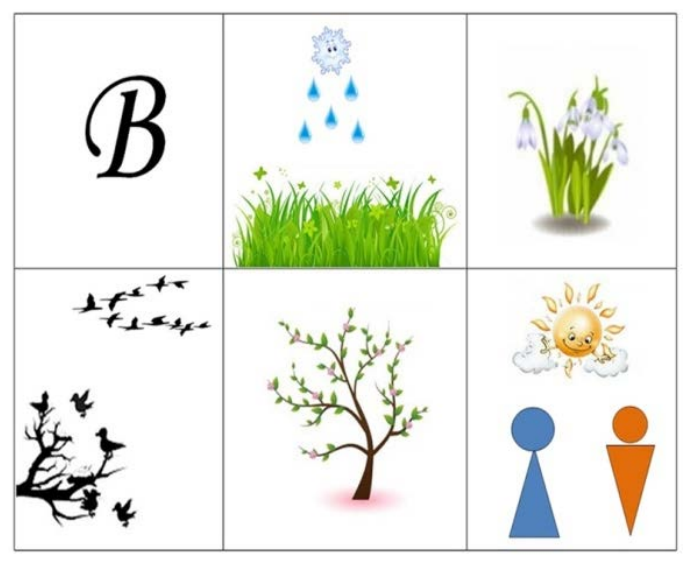

Гра Олині помічники

Mema: Вчити утворювати форми множини діеслів, зменшувально-пестливі форми іменників.

Обладнання: Лялька.

$X i \partial:$ Вихователь говорить дітям, що до них у гості прийшла лялька Оля зі своїми помічниками і пропонуе відгадати, як вони називаються і що допомагають Олі робити. Потім вихователь показуе, як лялька моргає і питае: «Що це у Олі? Це очі, Олині помічники. Що вони роблять? (Дивляться, моргають, відкриваються, закриваються, мружаться). А як їх назвати ласкаво? (Вічка)». Аналогічно розглядаються ноги, руки, вуха і т.д. Після цього вихователь читае дітям вірш Є.Г. Кірганової «Олині помічники», спонукаючи дітей додавати слово в кінці кожного четверо вірша:

Оля весело біжить

До річки по доріжці,

А для цього потрібні

Нашій Олі... (ніжки).

Оля ягідки бере

По дві, по три штучки.

А для цього потрібні

Нашій Олі ... (ручки).

Оля ядерця гризе,

Падають шкарлупки.

А для цього потрібні 


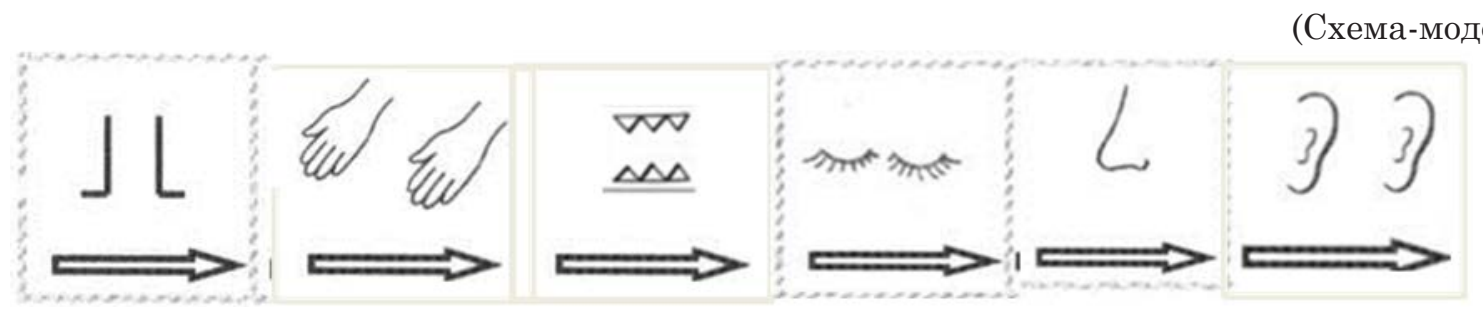

Нашій Олі ... (зубки).

На картинці - казці.

Оля дивиться на кішку,

А для цього потрібні

Нашій Олі ... (вічка).

Як пахне квіточка у полі,

Та ще й грибів кошик,

Для цього нашій Олі

Потрібен... (носик).

Щоб почути спів пташок,

Та як дзижчить мушка,

Для цього потрібні

Нашій Олі... (вушка).

Висновки 3 даного дослідження і перспективи. 3 показаної вище роботи ми бачимо: для того, щоб навчити дитину оперувати своїми мовними знаннями, необхідно використовувати у своій роботі різні методи та прийоми. Найбільш вдало допомагає саме метод наочного моделювання створити такі умови, в яких дитина може розвинути свої комунікативні здібності. Метод наочного моделювання дозволяе підвищити ефрективність мови дошкільників, може бути використаний в роботі з дітьми як засіб підвищення інтересу до даного виду діяльності та оптимізації процесу розвитку мовлення дітей дошкільного віку. Поступово опановуючи усіма видами зв'язного висловлювання за допомогою моделювання, діти вчаться планувати свою промову.

Мати певний вплив на комунікативний розвиток дошкільнят можна моделювати ситуації для спілкування. Тут дитина може показати вже набуті раніше навички і побудови різних типів речень, і лексичний запас, і показати результат формування граматичної будови мови. Такі мовні ситуації можуть бути: телефонна розмова, подорож, магазині, на виставці, прихід в гості, роз- мова 3 туристом та інше. При цьому дитина не тільки констатуе фракти про предмет, а і висловлюе своє ставлення, розмірковуе, обгрунтовує, оцінюе, робить висновки. Для таких ситуацій можуть бути використані схеми опису, складання речень. Діти оволодівають комунікативними навичками поведінки, навичками спілкування за правилами етикету в таких ситуаціях.

Використовуючи різні схеми зображення чи то предмета, чи то розповіді, чи то речення, дитина може розкрити свої потенщійні можливої в мовленневому розвитку. Наочна модель досить часто стає засобом подолання страху дитини перед складанням зв'язних розповідей. Цей вид розповіді передбачає вміння дитини створювати особливий задум і розгортати його в розповідь 3 різними деталями та подіями. Дитині пропонуеться модель розповіді, а вона має скласти розповідь і наділити елементи моделі змістовими якостями.

Опановують такими елементами спілкування в іграх навчаються, як вміння розпочати бесіду, підтримати іï, вміння цілеспрямовано слухати співрозмовника, ставити уточнюючі питання. У грі завжди представлена ситуація, яка створюється як вербальними, так і невербальними засобами. Таким чином, центром уваги партнерів стає зміст бесіди, що само по собі є позитивним засобом. Дошкільнята переконуються наочно в тому, що мову можна використовувати як засіб спілкування.

Таким чином, комунікація полягає в розвитку навичок і умінь різнобічного спілкування, встановлення конструктивних зв'язків і взаємин з оточуючими людьми. Розвиваючи комунікативну сореру у дітей, ми сприяемо успішної соціалізації дітей, розвиваємо навички відповідної поведінки і спілкування, як в родині, так і в соціумі.

\section{Список літератури:}

1. Базовий компонент дошкільної освіти (нова редакція) / Науковий керівник: А. М. Богуш, дійсний член НАПН України, проф., д-р пед. наук; Авт. кол-в: Богуш А. М., Беленька Г. В., Богініч О. Л., Гавриш Н. В., Долинна О. П., Ільченко Т. С., Коваленко О. В., Лисенко Г. М., Машовець М. А., Низковська О. В., Панасюк Т. В., Піроженко Т. О., Поніманська Т. І., Сідельнікова О. Д., Шевчук А. С., Якименко Л. Ю. Київ : Видавництво, 2012. 26 с.

2. Венгер Л. А., Венгер А. Л. Домашняя школа мышления. Москва : Просвещение, 1975. 313 с.

3. Коментар до Базового компонента дошкільної науки в Україні : наук.-метод. посіб. Наук. ред. О. Л. Кононко. Київ : Дошкільне виховання, 2003. № 4. С. 17.

4. Копилова О. В., Ткаченко В. М. Використання символів у роботі з дошкільниками. Харків : Вид-во «Ранок», 2009. $56 \mathrm{c}$.

5. Крутій К. Л., Кулинич О. П., Погрібняк Н. В. Конспекти занять із художньо-мовленневої діяльності дітей середнього дошкільного віку. Запоріжжя : ТОВ «ЛІПС» ЛТД, 2013. С. 85-96.

6. Осмоловская И. М. Наглядные методы обучения : учеб. пособ. для студ. высш. учеб. заведений. Москва : Изд. центр «Академия», 2009. 192 с.

7. Стецюк I. І. Метод наочного моделювання в роботі з дітьми із ЗНМ. Логопед. Харків : Вид. група «Основа», 2012. № 3. C. 13-23.

\section{References:}

1. Basic component of preschool education (new edition) (2012) / Supervisor: A.M. Bogush, a full member of the National Academy of Pedagogical Sciences of Ukraine, Prof., Dr. Ped. science; Author count: Bogush A.M., 
Belenka G.V., Boginich O.L., Gavrish N.V., Dolinna O.P., Ilchenko T.S., Kovalenko O.V., Lysenko G.M., Mashovets M.A., Nizkovska O.V., Panasyuk T.V., Pirozhenko T.O., Ponymanska T.I., Sidelnikova O.D., Shevchuk A.S., Yakymenko L.Yu. Kyiv: Publishing house, 26 p.

2. Wenger L.A., Wenger A.L. (1975) Home school of thinking. Moscow: Enlightenment, 313 p.

3. Commentary on the Basic component of preschool science in Ukraine (2003): scientific method. way. Science. ed. O.L. Kononko. Kyiv: Preschool education, no. 4, p. 17.

4. Kopylova O.V., Tkachenko V.M. (2009) The use of symbols in working with preschoolers. Kharkiv: Ranok Publishing House, $56 \mathrm{p}$.

5. Krutiy K.L., Kulinych O.P., Pogribnyak N.V. (2013) Abstracts of classes on artistic and speech activities of middle school children. Zaporozhye: LLC "LIPS" LTD, pp. 85-96.

6. Osmolovskaya I.M. (2009) Visual teaching methods: textbook. allowance. for students. higher textbook routine. Moscow: Ed. Center "Academy", 192 p.

7. Stetsyuk I.I. (2012) Method of visual modeling in work with children with ASD. Speech therapist. Kharkiv: Ed. Osnova group, no. 3, pp. 13-23. 